\title{
Heparan-Sulfate 6-O-Sulfotransferase 2
}

National Cancer Institute

\section{Source}

National Cancer Institute. Heparan-Sulfate 6-O-Sulfotransferase 2. NCI Thesaurus. Code C102553.

Heparan-sulfate 6-O-sulfotransferase 2 (605 aa, $69 \mathrm{kDa}$ ) is encoded by the human HS6ST 2 gene. This protein plays a role in the sulfation of proteoglycans. 